\title{
Article \\ A Simple and Reliable Single Tube Septuple PCR Assay for Simultaneous Identification of Seven Meat Species
}

\author{
Zhendong Cai ${ }^{1,2} \mathbb{D}$, Song Zhou ${ }^{1,2}$, Qianqian Liu ${ }^{3, *}$, Hui Ma ${ }^{1,2}$, Xinyi Yuan ${ }^{1,2}$, Jiaqi Gao ${ }^{1,2}$, Jinxuan Cao ${ }^{1,2} \mathbb{D}$ \\ and Daodong Pan 1,2,*
}

1 State Key Laboratory for Managing Biotic and Chemical Threats to the Quality and Safety of Agro-Products, Ningbo University, Ningbo 315211, China; zhendongcai@hotmail.com (Z.C.); zhousongluchen@163.com (S.Z.); m17805843103@163.com (H.M.); yxy13065810608@163.com (X.Y.); caidan1389@126.com (J.G.); caojinxuan@nbu.edu.cn (J.C.)

2 Key Laboratory of Animal Protein Deep Processing Technology of Zhejiang Province, College of Food and Pharmaceutical Sciences, Ningbo University, Ningbo 315800, China

3 Institute of Environmental Research at Greater Bay Area, Guangzhou University, Guangzhou 510006, China

* Correspondence: csuliuqian@foxmail.com (Q.L.); daodongpan@163.com (D.P.)

check for updates

Citation: Cai, Z.; Zhou, S.; Liu, Q.; Ma, H.; Yuan, X.; Gao, J.; Cao, J.; Pan, D. A Simple and Reliable Single Tube Septuple PCR Assay for Simultaneous Identification of Seven Meat Species. Foods 2021, 10, 1083. https://doi.org/10.3390/ foods10051083

Academic Editors:

Mohammed Gagaoua and Brigitte Picard

Received: 14 March 2021

Accepted: 10 May 2021

Published: 13 May 2021

Publisher's Note: MDPI stays neutral with regard to jurisdictional claims in published maps and institutional affiliations.

Copyright: (c) 2021 by the authors. Licensee MDPI, Basel, Switzerland. This article is an open access article distributed under the terms and conditions of the Creative Commons Attribution (CC BY) license (https:/ / creativecommons.org/licenses/by/ $4.0 /)$.

\begin{abstract}
Multiplex PCR methods have been frequently used for authentication of meat product adulteration. Through screening of new species-specific primers designed based on the mitochondrial DNA sequences, a septuple PCR method is ultimately developed and optimized to simultaneously detect seven species including turkey (110 bp), goose (194 bp), pig (254 bp), sheep (329 bp), beef (473 bp), chicken (612 bp) and duck (718 bp) in one reaction. The proposed method has been validated to be specific, sensitive, robust and inexpensive. Taken together, the developed septuple PCR assay is reliable and efficient, not only to authenticate animal species in commercial meat products, but also easily feasible in a general laboratory without special infrastructures.
\end{abstract}

Keywords: septuple PCR; adulteration; meat species; mitochondrial genes; multiplex PCR

\section{Introduction}

Meat authentication is an important concern to protect consumers from illegal and unwanted ingredients [1-4]. However, meat adulteration such as unlisted, mislabeled or fraudulent ingredients has frequently been reported around the world and has become a severe global issue $[4,5]$. Although some laws have been enacted for ensuring the quality and safety of meat products, adulteration is still widespread due to the purpose of economic pursuit $[1,6]$. Poultry meat (chicken, duck and goose), especially, is frequently adulterated to red meat due to their low cost of production in Chinese markets [1,7]. As is known, soy allergy has become an arising public health concern regarding food allergies, as a small amount of soybean may elicit allergic reactions in both children and adults [8]. Notably, there is increasing evidence supporting that meat may trigger allergic reactions, especially for sensitized patients, which may cause a severe health risk of infectious diseases, metabolic disorders and allergies [9]. In addition, meat adulteration could also violate religious concerns; as is known, meat products containing pork ingredients are not permitted by Kosher and Halal food laws [10,11]. Therefore, it remains a pressing need for identifying meat species with $100 \%$ accuracy in real-world foodstuffs.

In recent years, the techniques for authenticating meat species have been continuously evolving. Many analytical methods of biological, immunological, physical, chemical, anatomical and histological analyses have been developed [2-4,7,12]. Among them, proteinbased methods are widely used to identify meat species in composite mixtures $[5,13]$. Proteins are likely to be degraded, denatured or damaged in processed meat products, limiting the accuracy of the identification of meat species in thermally treated foods $[13,14]$. In comparison, DNA-based analytical methods coupled with polymerase chain reaction 
(PCR) present a reliable alternative to protein-based methods in the discrimination and mislabeling detection of meat species, as DNA molecules possess high stability and are present in every type of cell $[4,5]$. Both multiplex and real-time PCR techniques are highly specific and efficient in the identification of meat adulteration [15]. Real-time PCR techniques are widely used to quantify the amount of a target sequence in a reaction system. The levels of PCR amplification are monitored in real time, once per cycle, by measuring specific fluorescence signals, whose intensities reflect the amount of PCR product [16]. With the progress of molecular biology in recent years, multiplex real-time PCR techniques depending on melting curve analysis have been developed and widely adopted in the identification of meat species, and they have characteristics such as time saving, high specificity and high sensitivity [17-20]. Collectively, real-time PCR analysis shows more detailed information with regard to the identification and quantification of meat species. However, accurate quantification can only be achieved with a proper reference material because the matrix may interfere with the amplification process [21], indicating that quantification of meat fractions in real-world foodstuffs is difficult, and the results may not truly correlate to the recipe of the meat products. In comparison, multiplex PCR assay can be easily implemented with minimum effort, but much gain, to verify the identification of meat species. Recently, many studies have also constructed multiplex PCR with electrophoresis analysis to authenticate meat species with satisfying results [1]. Although much is known about multiplex PCR as duplex, triplex, tetraplex, pentaplex (quintuple) and hexaplex (sextuple) PCRs, little information is available on a multiplex PCR authenticating more than six animal species simultaneously.

Mitochondrial DNA possesses high copy numbers per cell and strong stability, which ensures a low limit of detection and its availability in both raw and cooked meat products, and it has been broadly adopted for PCR protocols [22,23]. For example, cytochrome $b$ gene, D-loop, 12S and 16S rRNA genes, ATPase subunits 8 and 6 genes, and NADH dehydrogenase genes are common targets for identifying meat species [21,24,25]. All data provide reliable evidence for the roles of mitochondrial DNA sequences in animal species identification. Using mitochondrial DNA sequences obtained from turkey, goose, pig, sheep, beef, chicken and duck, we designed a set of primer pairs that specifically amplified for seven species with differential lengths through PCR assays. We next performed the specific, sensitive and cost-effective detection of the indicated primers through simplex and multiplex PCR assays. Through screening, this study develops a septuple PCR assay for identifying seven ingredients of turkey, goose, pig, sheep, beef, chicken and duck simultaneously in commercial foodstuffs.

\section{Materials and Methods}

\subsection{Preparation of Meat Samples and DNA Extraction}

Fresh meat samples of turkey, goose, pig, sheep, beef, chicken and duck were purchased from local retailers and markets and transported on ice to the laboratory for immediate processing. Samples were stored at $-20^{\circ} \mathrm{C}$ to prevent DNA degradation. Total DNA was extracted from various meat samples using the EasyPure ${ }^{\circledR}$ Genomic DNA Kit (Beijing Trans Gen Biotech Co., Ltd., Beijing, China) following the manufacturer's instructions. DNA concentration was determined by a NanoDrop 2000 UV-Vis spectrophotometer (Thermo Scientifc, Wilmington, DE, USA).

\subsection{Design of Species-Specific Primers}

Primers were designed by targeting mitochondrial DNA sequences based on both high divergence and conservation within the species. As shown in Table 1, sequences of 16S rRNA gene of turkey (GenBank Accession No. EF153719.1), 16S rRNA gene of goose (KJ124555.1), cytochrome $c$ oxidase subunit I gene of pig (KJ746666.1), cytochrome $c$ oxidase subunit I gene of sheep (KP702285.1), 16S rRNA gene of cattle (MN714195.1), cytochrome $b$ gene of chicken (MK163565.1) and 12S rRNA gene of duck (MK770342.1) were obtained from the National Centre of Biotechnology Information (NCBI) database. Next, the MEGA6 alignment tool 
was employed for identifying the conservative and variable regions. Using Oligo 7.0 and BLAST programs (www.ncbi.nlm.nih.gov/blast/ accessed on 1 April 2021), primers were newly designed according to their physical parameters, such as melting temperature, secondary structures, self-complementarity and cross-reactivity. The primer pairs were synthesized by Shanghai Sangon Biological Engineering Technology \& Services Co., Ltd. (Shanghai, China). To determine the mismatch between the target and nontarget species, each set of primers was in silico screened with 13 land animals: turkey (Meleagris gallopavo), goose (Anser cygnoides), pig (Sus scrofa), cattle (Bos taurus), sheep (Ovis aries), chicken (Gallus gallus), duck (Anas platyrhynchos), horse (Equus caballus), camel (Camelus bactrianus), ostrich (Struthio camelus), dog (Canis lupus), rabbit (Oryctolagus cuniculus), cat (Felis catus) and 3 aquatic species, namely, small yellow croaker (Larimichthys polyactis), tuna (Thunnus orientalis) and black carp (Mylopharyngodon piceus), using ClustalW software. The final specificity of each primer pair was examined through PCR assays against templates of all species mentioned above.

Table 1. Oligonucleotide primers for meat species used in this study.

\begin{tabular}{|c|c|c|c|c|}
\hline Primers & Genes & Sequence $\left(5^{\prime}-3^{\prime}\right.$ Direction) & Amplicons (bp) & $\begin{array}{l}\text { Reference or } \\
\text { Source }\end{array}$ \\
\hline Turkey & 16S rRNA & $\begin{array}{l}\text { CTCTAGCCCAACCACCCAT } \\
\text { GCGCCTAAGGTCTTTTCTATCAC }\end{array}$ & 110 & this study \\
\hline Goose & 16S rRNA & $\begin{array}{l}\text { TTAGACGCGATAGAGACCCCA } \\
\text { GTTCGCTCTCTTTAACTGCTTG }\end{array}$ & 194 & this study \\
\hline Pig & cytochrome c oxidase subunit I & $\begin{array}{l}\text { CAGCCCGGAACCCTACTTG } \\
\text { GTTCATCCAGTACCCGCTCC }\end{array}$ & 254 & this study \\
\hline Sheep & cytochrome c oxidase subunit I & $\begin{array}{l}\text { AGATATCGGCACCCTTTACCTTC } \\
\text { CTGCTCCGGCCTCAACCAT }\end{array}$ & 329 & this study \\
\hline Beef & 16S rRNA & $\begin{array}{l}\text { GTGCCTGATAATACTCTGACCAC } \\
\text { CACCCCAACCGAAACTACCAA }\end{array}$ & 473 & this study \\
\hline Chicken & cytochrome b & $\begin{array}{l}\text { TTTCGGCTCCCTATTAGCAGTC } \\
\text { AGTATGAGAGTTAAGCCCAGA }\end{array}$ & 612 & this study \\
\hline Duck & $12 \mathrm{~S}$ rRNA & $\begin{array}{l}\text { TGCCCTCAATAGCCTTCACC } \\
\text { CATACTTCTTTCCGTGTTGCC }\end{array}$ & 718 & this study \\
\hline Eukaryotes & 12S rRNA & $\begin{array}{l}\text { CAACTGGGATTAGATACCCCACTAT } \\
\text { GAGGGTGACGGGCGGTGTGT }\end{array}$ & 456 & [26] \\
\hline Eukaryotes & 16S rRNA & $\begin{array}{l}\text { AAGACGAGAAGACCCTATGGA } \\
\text { GATTGCGCTGTTATCCCTAGGGTA }\end{array}$ & 240 & [27] \\
\hline Eukaryotes & 18S rRNA & $\begin{array}{l}\text { AGGATCCATTGGAGGGCAAGT } \\
\text { TCCAACTACGAGCTTTTTAACTGCA }\end{array}$ & 99 & [28] \\
\hline
\end{tabular}

\subsection{Simplex and Multiplex $P C R$}

To develop a multiplex PCR method, simplex PCR was firstly carried out for each of the target species with their own primers to ensure that each target was amplified. PCR amplification (in one reaction of $25 \mu \mathrm{L}$, including $2.5 \mu \mathrm{L}$ of $10 \times$ EasyTaq $^{\circledR}$ Buffer, $2 \mu \mathrm{L}$ of $2.5 \mathrm{mM}$ dNTPs, $0.5 \mu \mathrm{L}$ of EasyTaq DNA Polymerase, $0.5 \mu \mathrm{L}$ of $10 \mu \mathrm{M}$ each primer, and 0.01-10 ng genomic DNA of each species) was achieved using EasyTaq ${ }^{\circledR}$ DNA Polymerase kit (TransGen Biotech Co., Ltd., Beijing, China). The reaction was initiated by a 5 min denaturation at $94{ }^{\circ} \mathrm{C}$, followed by 34 cycles of denaturation at $94{ }^{\circ} \mathrm{C}$ for $30 \mathrm{~s}$, annealing at $63{ }^{\circ} \mathrm{C}$ for $30 \mathrm{~s}$, elongation at $72{ }^{\circ} \mathrm{C}$ for $45 \mathrm{~s}$ and a final elongation at $72{ }^{\circ} \mathrm{C}$ for $5 \mathrm{~min}$. For universal primer pairs, the annealing was set at $56^{\circ} \mathrm{C}$. After simplex PCR assays for each species was achieved, a septuple PCR assay was developed. The $4 \%$ agarose gels were visualized and subsequently photographed in a Bio-rad GelDoc 1000 gel documentation system.

\subsection{Test of Primers' Specificity, Sensitivity and Reproducibility}

The specificity of species-specific primers was corroborated by using template DNA isolated from all species (turkey, goose, pig, cattle, sheep, chicken, duck, horse, camel, ostrich, dog, rabbit, cat, small yellow croaker, tuna, black carp). In the preliminary phase 
of this experiment, simplex and septuple PCRs were respectively performed by using the DNA extracted from raw animal species. The PCR product was run on agarose gel and then visualized for the proper amplification.

The sensitivity of septuple PCR assay was confirmed by serial dilutions of the premixed DNA templates of all target species indicated, starting with $10 \mathrm{ng}$ and progressing downward in one reaction. Seven concentrations (10 ng to $0.01 \mathrm{ng}$ ) of the target templates were used for PCR amplification determining the minimal concentration detected. PCR fragments were run on $4 \%$ agarose gel to confirm the limit of detection.

To assess the reproducibility, template DNA isolated from raw, boiled $\left(97-99{ }^{\circ} \mathrm{C}\right.$, $30 \mathrm{~min})$, autoclaved $\left(121^{\circ} \mathrm{C}, 150 \mathrm{kPa}\right.$ for $\left.15 \mathrm{~min}\right)$ and microwave-cooked $(750 \mathrm{~W}, 10 \mathrm{~min}$, $119-121^{\circ} \mathrm{C}$ ) meat samples were individually analyzed by using the simplex PCR. The PCR product was run on agarose gel.

\subsection{Commercial Samples}

Using the present multiplex PCR method, 60 raw or thermally processed meat products including meat balls (15), meat slices (13), kebab (10), sausages (5), cutlets (10), jerky (2) and breast (5) were purchased from retail markets and supermarkets in Ningbo City, PR China, as well as online supermarket platforms, which were used for assessing the authentication of meat species. Details of the samples are listed in Table 2. All samples of meat balls, slices, kebabs, sausages, cutlets and breasts were raw materials with mechanical processing but not heat treatment, while two jerky samples, within turkey, were subjected to heat processing.

Table 2. Results of multiplex PCR assay performed on commercial meat products.

\begin{tabular}{|c|c|c|c|c|c|c|c|c|c|c|}
\hline \multirow{2}{*}{ Products } & \multirow{2}{*}{ No } & \multirow{2}{*}{ Labelled } & \multicolumn{7}{|c|}{ Detected Species } & \multirow{2}{*}{ Adulteration } \\
\hline & & & Turkey & Goose & Pig & Sheep & Beef & Chicken & Duck & \\
\hline Beef & 15 & & & & & & & & & $5(33.3 \%)$ \\
\hline meat balls & 5 & beef & $1 / 5^{b}$ & - & $1 / 5^{a}, 1 / 5^{b}$ & - & $5 / 5$ & $1 / 5^{a}$ & - & \\
\hline meat slices & 5 & beef & - & - & $1 / 5$ & - & $5 / 5$ & - & - & \\
\hline kebab & 5 & beef & & - & $2 / 5$ & - & $5 / 5$ & - & - & \\
\hline Mutton & 15 & & & & & & & & & $6(40.0 \%)$ \\
\hline meat balls & 5 & mutton & - & - & $1 / 5^{a}, 1 / 5^{b}$ & $5 / 5$ & - & $1 / 5^{\mathrm{a}}$ & $1 / 5^{b}$ & \\
\hline meat slices & 5 & mutton & - & - & $2 / 5$ & $5 / 5$ & - & - & - & \\
\hline kebab & 5 & mutton & - & - & $2 / 5$ & $5 / 5$ & - & - & - & \\
\hline Pork & 15 & & & & & & & & & $4(26.7 \%)$ \\
\hline meat balls & 5 & pig & - & $1 / 5^{b}$ & $5 / 5$ & - & - & $\begin{array}{l}1 / 5^{\mathrm{a}} \\
1 / 5^{\mathrm{b}^{\prime}}\end{array}$ & $1 / 5^{a}$ & \\
\hline sausages & 5 & pig & - & - & $5 / 5$ & - & - & $1 / 5^{a}$ & $1 / 5^{b}$ & \\
\hline cutlets & 5 & pig & - & - & $5 / 5$ & - & - & - & - & \\
\hline Turkey & 15 & & & & & & & & & \\
\hline cutlets & 5 & turkey & $5 / 5$ & - & - & - & - & $1 / 5$ & - & $1(6.7 \%)$ \\
\hline meat slices & 3 & turkey & $3 / 3$ & - & - & - & - & - & - & \\
\hline breast & 5 & turkey & $5 / 5$ & - & - & - & - & - & - & \\
\hline jerky & 2 & turkey & $2 / 2$ & - & - & - & - & - & - & \\
\hline
\end{tabular}

A horizontal line (-) denotes no PCR product detected. In each row, the meat samples labeled with same letter $\left({ }^{\mathrm{a}}\right.$ or $\left.{ }^{\mathrm{b}}\right)$ represent the identical meat samples, while different letters indicate a difference in meat samples.

\section{Results}

\subsection{Specificity Assays of Simplex PCR}

To determine the species-specific primers, we designed many pairs of primers for each species as candidates by using Oligo 7.0 and BLAST programs. Each set of primers was compared against 16 species (turkey, goose, pig, cattle, sheep, chicken, duck, horse, camel, ostrich, dog, rabbit, cat, small yellow croaker, tuna and black carp) by simplex PCR assays (data not shown). Through gel electrophoresis, we ultimately selected the primer 
pairs for each species in Table 1. PCR fragments showed distinguishable bands with the predicted size of 110, 194, 254, 329, 473, 612 and 718 bp for turkey, goose, pig, sheep, beef, chicken and duck species, respectively (Figure 1A). Three pairs of universal eukaryotic primers, which target 12S rRNA, 16S rRNA and 18S rRNA genes with individual 456, 240 and $99 \mathrm{bp}$ PCR fragments in all meat species, were used as positive controls for ensuring the quality of template DNAs in one PCR reaction (Figure 1B). To further test the efficiency and specificity of primers, simplex PCRs were carried out using a DNA mixture of all seven meat species. In these experiments, each set of species-specific primers yielded the expected PCR fragment by using only the template DNA mixture of seven meat species, but not with nontarget species (Figure 1C), further confirming that the new primers were highly specific for the target species.
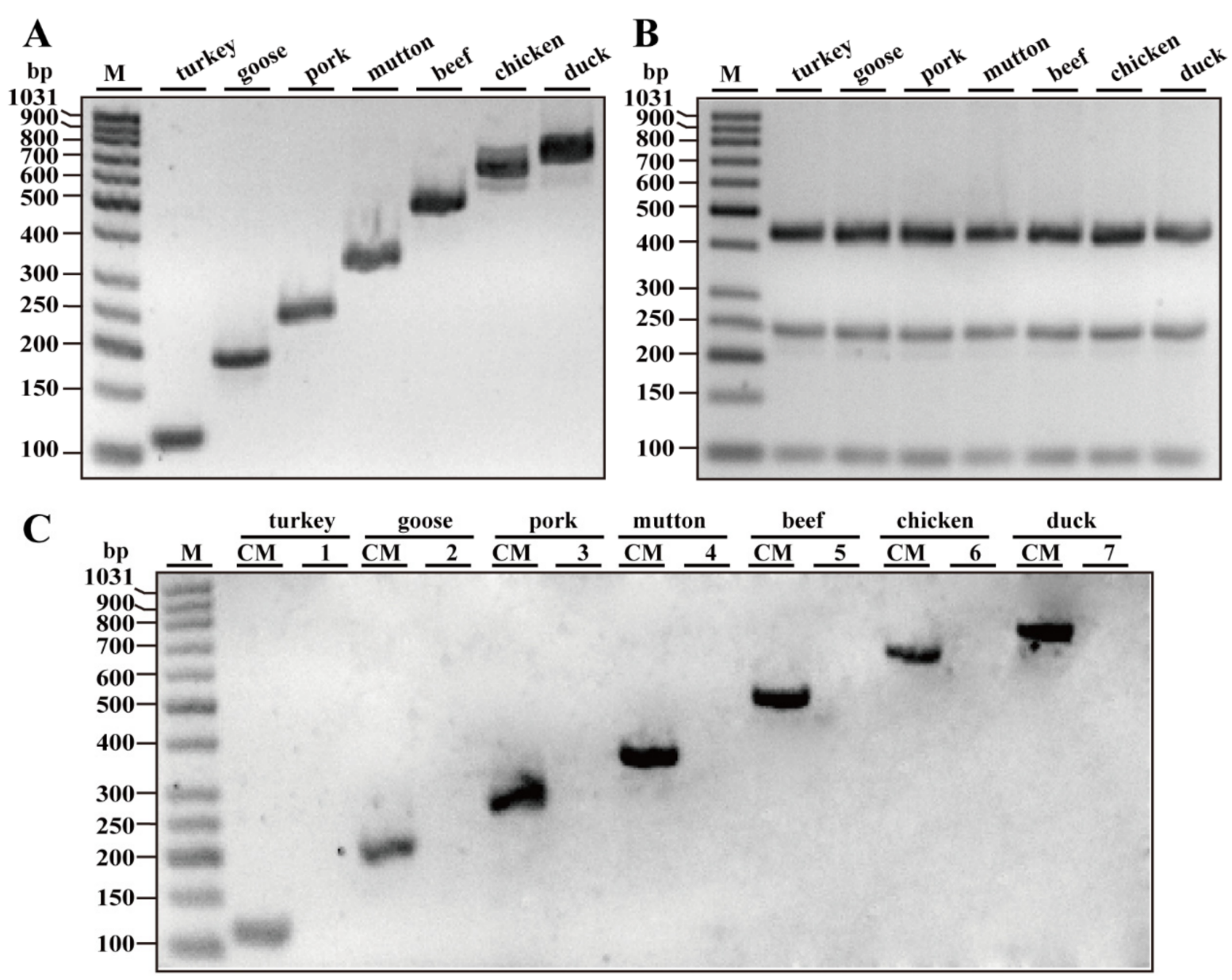

Figure 1. Specificity assays of simplex PCR. (A) Gel image of the products generated by PCR amplification with speciesspecific primers for turkey, goose, pig, cattle, sheep, chicken and duck using corresponding genomic DNA as a template, respectively. (B) As positive controls, gel image of the PCR products generated after amplification with premixed universal eukaryotic primer pairs of 12S rRNA, 16S rRNA and 18S rRNA genes for all meat species. (C) Gel image of the products through simplex PCR amplification using species-specific primers for turkey, goose, pig, cattle, sheep, chicken and duck. $\mathrm{CM}$, a complete mixture of turkey, goose, pig, cattle, sheep, chicken and duck; 1-7, a complete DNA mixture except target species DNA. Lane $\mathrm{M}$ is ladder DNA.

\subsection{Sensitivity Assays of Septuple PCR}

A septuple PCR system was constructed by using seven sets of species-specific primers. To validate the sensitivity of the multiplex PCR assay, extracted DNA of each target species was serially diluted $(10,5,1,0.5,0.1,0.05$ and $0.01 \mathrm{ng})$. PCR products were subsequently run on an agarose gel to assess the sensitivity. As can be seen from Figure 2A, 
the expected bands of seven meat species were obtained by multiplex PCR under the conditions of all tested concentrations (10-0.01 ng). In accordance with that of gel-view, each electropherogram clearly represented seven peaks corresponding to the seven different bands displayed in the gel-view (Figure 2B). Both intensities of bands and peaks were dramatically decreased in a concentration-dependent manner. However, even at the concentration of $0.01 \mathrm{ng}$ per reaction, some PCR products of meat species can be clearly recognized in Figure 2A,B. Thus, the limit of detection of the developed septuple PCR assay was concluded to be $0.01-0.05$ ng DNA.
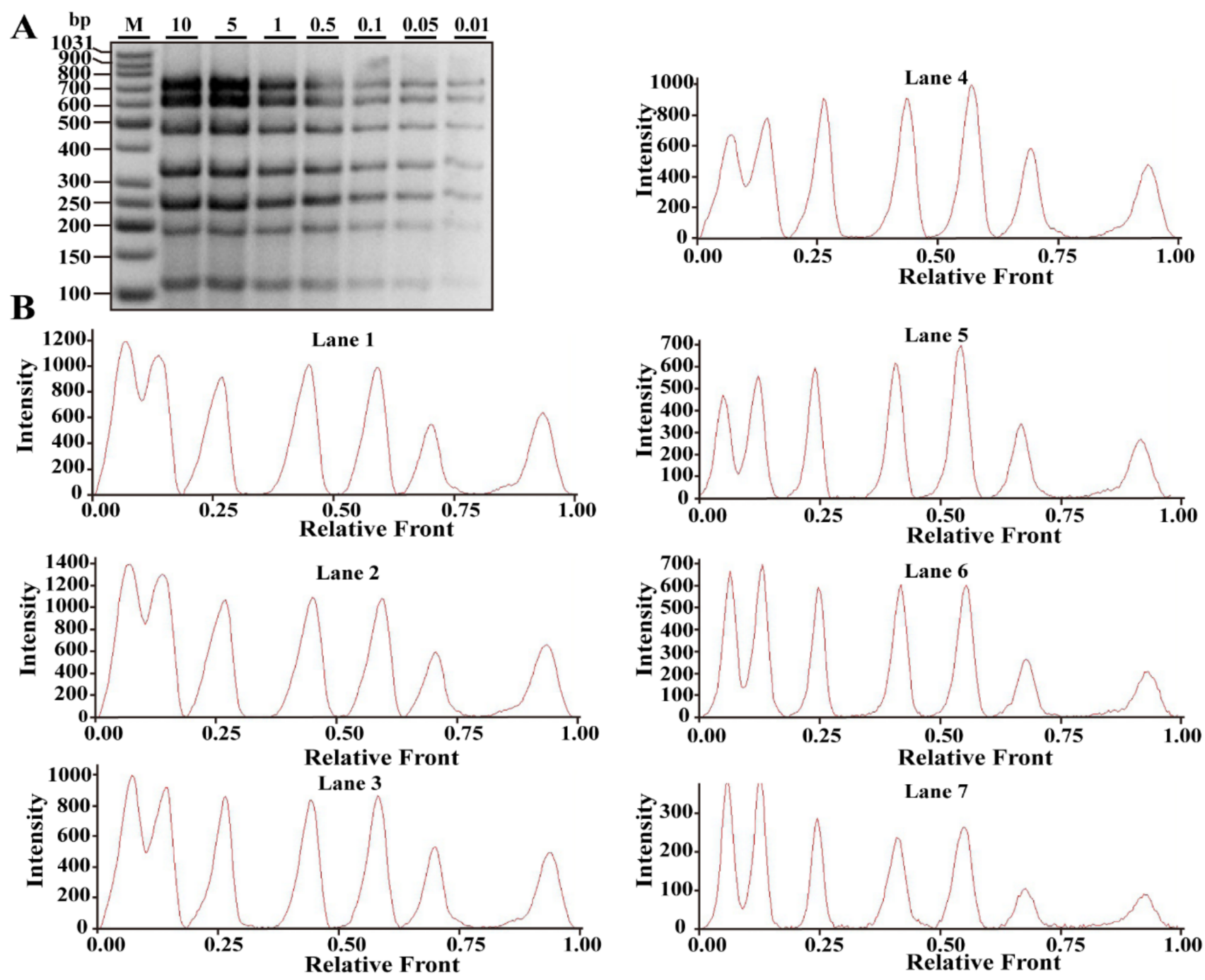

Figure 2. Sensitivity of the developed septuple PCR assay. (A) Gel image of the products generated after multiplex PCR amplifications of premixed DNA templates of all species $(10,5,1,0.5,0.1,0.05,0.01 \mathrm{ng})$ with primers of seven meat species mixtures including turkey, goose, pig, cattle, sheep, chicken and duck. (B) The corresponding electropherograms of gel image (A). Lanes 1-7 are presented with labels $(10,5,1,0.5,0.1,0.05,0.01)$ in (A). Lane M is ladder DNA.

\subsection{Validation of Reproducibility Assay in Thermally Processed Meat}

To assess the efficiency of designed primers in detecting thermally processed meat, three different heat treatment processes were selected to treat raw meat samples as described in Section 2.4. The quality of template DNA extracted from processed meat samples was examined by simplex PCR assays. As shown in Figure 3A-D, using DNA extracted from raw, boiled, autoclaved and microwave-cooked meat samples, PCR amplification of turkey, goose, pig, sheep, beef, chicken and duck species generated the expected PCR 
products with $100 \%$ accuracy in meat authentication, indicating that our designed primers can be successfully employed for authenticating animal species in processed meat products.
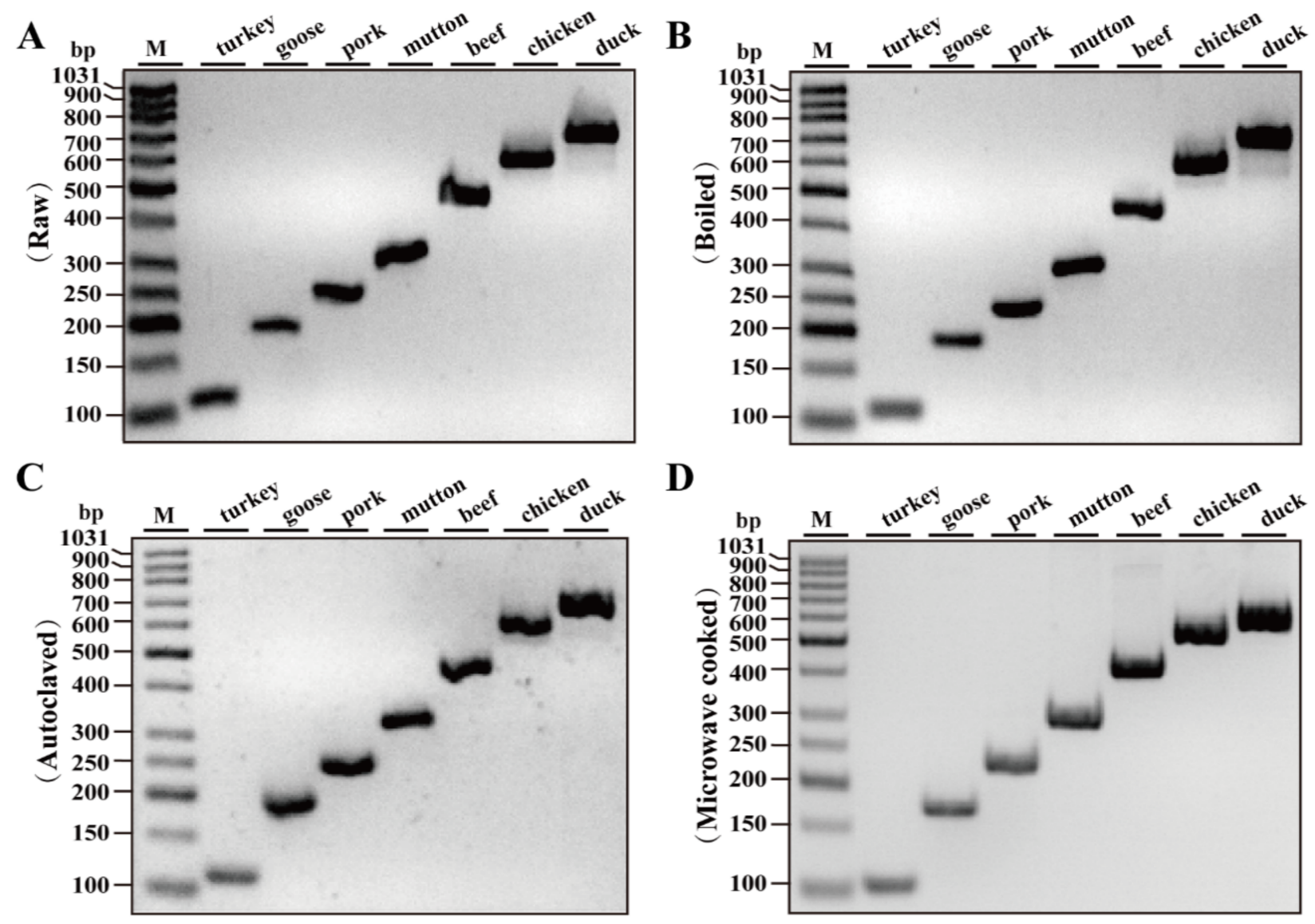

Figure 3. Gel image of the PCR products generated by simplex PCR amplifications with turkey, goose, pig, cattle, sheep, chicken and duck DNA extracted from raw (A), boiled (B), autoclaved (C) and microwave-cooked meat samples (D) using each species-specific primer pair. Lane $\mathrm{M}$ is ladder DNA.

\subsection{Application of Multiplex PCR Assay on Commercially Processed Meat Products}

The real-world food products were examined using the developed septuple PCR. The survey was conducted with 60 commercial samples of beef, mutton, pork and turkey (15 samples each). As shown in Figure 4 and summarized in Table 2, most of the samples had the same ingredients as labeled, without contamination. However, 5 of 15 (33.3\%) beef samples, 6 of $15(40.0 \%)$ mutton samples, 4 of $15(26.7 \%)$ pork samples and 1 of $15(6.7 \%)$ turkey samples contained some unlisted meat species. The survey revealed that inexpensive chicken, duck and pork meats were frequently adulterated products. The results further corroborated the efficiency of the developed septuple PCR assay in identification of commonly consumed meats. 


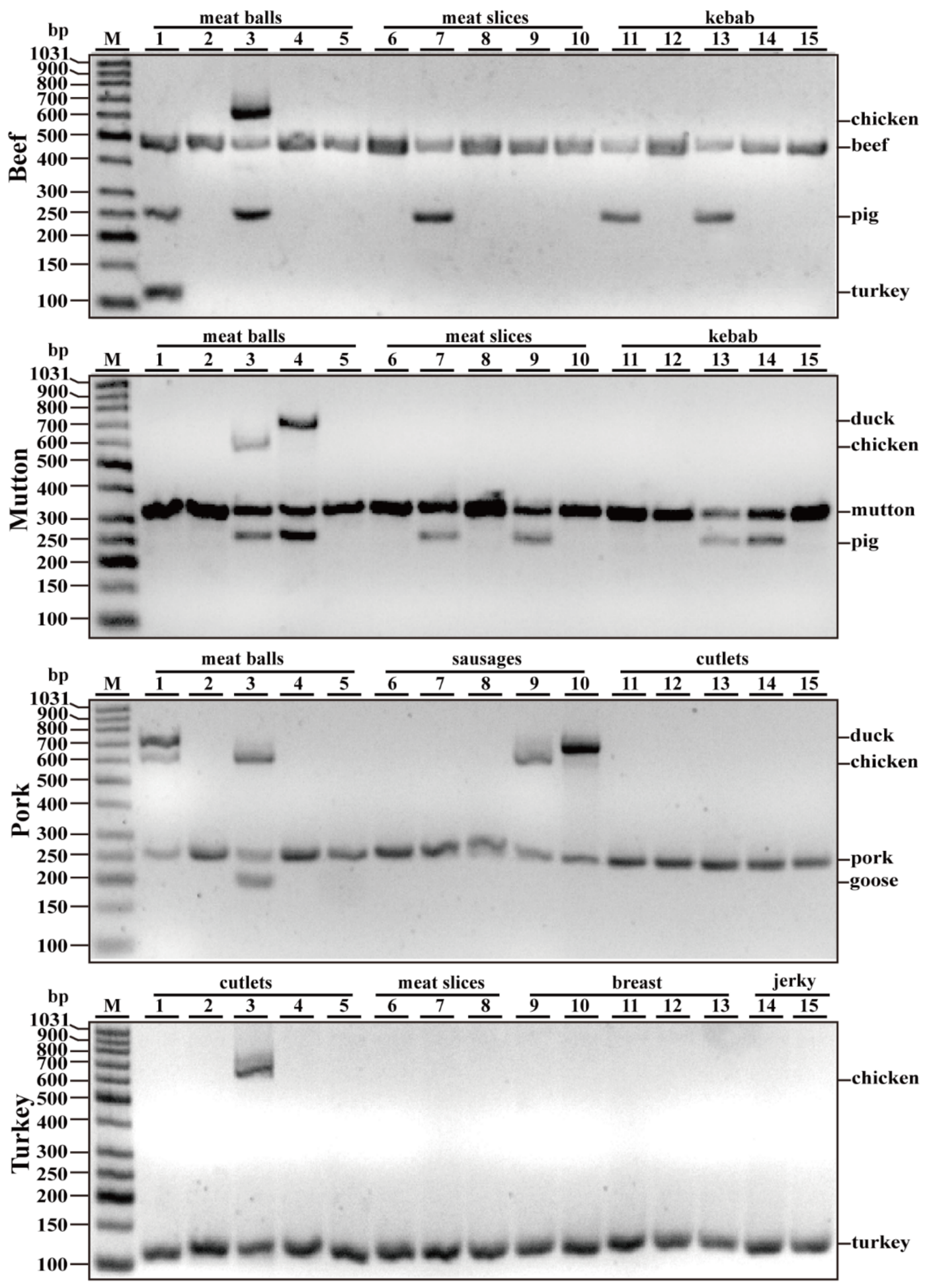

Figure 4. Analysis of commercial foodstuffs using the developed septuple assay. Gel image of the fragments generated by multiplex PCR amplifications using DNA obtained from commercial meat products with premixed primers for seven meat species including turkey, goose, pig, cattle, sheep, chicken and duck.

\section{Discussion}

Frequent meat frauds have aroused significant social attention because adulteration risks food safety, breaches market rules and even threatens public health [8]. In recent years, adulteration practice has been ingeniously applied to treated meat products showing 
similar morphological and physical appearance to pure meat. Nowadays, PCR-based techniques are the effective methods for species authentication. Real-time PCR techniques and microchip electrophoresis-dependent multiplex PCR methods require special infrastructures [11,29,30]; multiplex PCR assays through simple agarose gel analysis minimizes the cost drastically on a large scale and can be easily carried out to verify the identity of ingredients in foodstuffs $[6,31,32]$. As seen in Table 3, much is known about multiplex PCR assays that simultaneously verify two to six meat ingredients in one reaction. Relatively little information is available on multiplex PCR methods for authenticating more meat species simultaneously. Although one study authenticated 10 animal species (beef, sheep, pork, chicken, turkey, cat, dog, mouse, rat, human), it was achieved by two tube multiplex assays, where every five animal species were verified by a pentaplex PCR assay in one reaction [33]. Similarly, using two tube independent pentaplex PCR assays with ten pairs of primers, 14 animal species including cattle, donkey, Canidae (dog, fox, raccoon-dog), deer and horse, pig, Ovis (sheep, goat), poultry (chicken, duck), cat and mouse were detected through chip electrophoresis; however, the multiplex PCR failed to accurately distinguish sheep and goat within Ovis, dog, fox and raccoon-dog within Canidae, and chicken and duck within poultry [11]. Therefore, there is still a lack of more efficient detection methods with low cost for supervising more meat content. The goal of the present study was to develop a multiplex PCR method for reliable and efficient identification of ruminant, poultry and pork materials.

The choice of animal species was considered based on actual adulteration cases, with a higher practicability in Chinese markets. We found that multiplex PCR with increased species-specific primers in one reaction led to more opportunities of cross-reactivity with each other, or generated unexpected bands, which may limit the availability of multiplex PCR for verifying more animal species. To provide a multiplex PCR method that detects more animal species in a single assay platform, we designed many sets of primers throughout target mitochondrial DNA sequences such as cytochrome b gene, D-loop, 12S and $16 \mathrm{~S}$ rRNA genes, ATPase subunits 8 and 6 genes and NADH dehydrogenase genes using Oligo 7.0 and Primer-BLAST programs. Through screening species-specific primer pairs, a species-specific septuple PCR method was ultimately developed and optimized to simultaneously detect turkey (110 bp), goose (194 bp), pig (254 bp), sheep (329 bp), beef (473 bp), chicken (612 bp) and duck (718 bp) in one reaction. To ensure the quality of template genomic DNA in one PCR reaction, a universal eukaryotic primer set that amplifies a bigger PCR fragment than that of all meat species tested should be chosen as the preferred positive control. However, to our knowledge, little information is available on a universal eukaryotic primer set amplifying the fragment with more than $700 \mathrm{bp}$ length. As alternatives, we chose three pairs of universal eukaryotic primers, which target different mitochondrial DNA sequences, including 12S rRNA, 16S rRNA, 18S rRNA genes, and amplifies distinguishable 456, 240 and 99 bp PCR fragments in all meat species, respectively [26-28]. In addition, the control primer set should be inserted in the multiplex assay; these PCR fragments were too close to that of turkey (110 bp), pig (254 bp) and beef (473 bp) to discriminate each other. Accordingly, these universal primer pairs were used in a single PCR in this study. Figure $1 \mathrm{~B}$ shows the expected bands of each primer set in all meat species, implying the high quality of genomic DNA used in this study. 
Table 3. Comparative analysis of recently published multiplex PCR assays for the identification of meat species.

\begin{tabular}{|c|c|c|c|c|c|}
\hline $\begin{array}{l}\text { Multiplex PCR } \\
\text { Type }\end{array}$ & Sp. No ${ }^{a}$ & Detection Items & Detection Limit & $\begin{array}{l}\text { Detection } \\
\text { Method }^{b}\end{array}$ & $\begin{array}{l}\text { Reference } \\
\text { or Source }\end{array}$ \\
\hline Septuple & 7 & $\begin{array}{l}\text { turkey, goose, pig, sheep, beef, } \\
\text { chicken, duck }\end{array}$ & 0.01-0.05 ng DNA & Gel & $\begin{array}{l}\text { This } \\
\text { study }\end{array}$ \\
\hline Multiplex & 4 & $\begin{array}{l}\text { ruminant, poultry, pork, and } \\
\text { donkey }\end{array}$ & $0.01-0.1 \mathrm{ng} / \mu \mathrm{L}$ DNA & Gel & {$[25]$} \\
\hline Hexaplex & 6 & $\begin{array}{c}\text { chicken, cow/buffalo, } \\
\text { sheep/goat, horse/donkey, pork, } \\
\text { dog }\end{array}$ & 0.03-0.05 ng DNA & Gel & {$[31]$} \\
\hline Multiplex & 5 & $\begin{array}{c}\text { sheep/goat, bovine, chicken, } \\
\text { duck, pig }\end{array}$ & 0.5 ng DNA & Gel & [6] \\
\hline Multiplex & 2 & cattle, buffalo & 2.23-2.31 ng/ $\mu \mathrm{L}$ DNA & Gel & [34] \\
\hline Quadruple & 4 & $\begin{array}{c}\text { fox, mink, or raccoon in beef and } \\
\text { mutton }\end{array}$ & $1 \%$ for each species & Gel & [35] \\
\hline Pentaplex & 5 & $\begin{array}{l}\text { dog, duck, buffalo, goat, sheep } \\
\text { cattle, donkey, Canidae (dog, fox, }\end{array}$ & 0.1-0.32 ng DNA & Gel & [21] \\
\hline Multiplex (two-tube) & 14 & $\begin{array}{l}\text { raccoon-dog), deer and horse, pig, } \\
\text { Ovis (sheep, goat), poultry } \\
\text { (chicken, duck), cat, mouse }\end{array}$ & $0.02-0.2$ ng DNA & Chip & [11] \\
\hline Quadruplex & 4 & chicken, mutton, beef, pork & $\begin{array}{l}16 \text { pg DNA, } 0.01 \% \text { of } \\
\text { each species }\end{array}$ & Gel & [36] \\
\hline Multiplex (two-tube) & 10 & $\begin{array}{l}\text { beef, sheep, pork, chicken, turkey, } \\
\text { cat, dog, mouse, rat, human }\end{array}$ & 30 pg DNA & Gel & [33] \\
\hline Tetraplex & 3 & $\begin{array}{c}\text { pig, cattle, fish, eukaryotic18S } \\
\text { rRNA }\end{array}$ & $0.001-0.1$ ng DNA & Gel & [37] \\
\hline Hexaplex & 6 & $\begin{array}{l}\text { horse, soybean, sheep, poultry, } \\
\text { pork, cow }\end{array}$ & $0.01 \%$ for each species & Gel & {$[38]$} \\
\hline Octuplex & 8 & $\begin{array}{l}\text { dog, chicken, cattle, pig, horse, } \\
\text { donkey, fox, and rabbit }\end{array}$ & $0.05 \mathrm{ng} / \mu \mathrm{L}$ DNA & Gel & [27] \\
\hline Multiplex & 3 & chicken, duck and goose & $\begin{array}{l}0.05 \text { ng DNA, } 1 \% \text { for } \\
\text { each species }\end{array}$ & Gel & {$[39]$} \\
\hline Multiplex & 5 & cat, dog, pig, monkey, rat & $0.01-0.02$ ng DNA & Chip & [24] \\
\hline Quadruple & 4 & beef, pork, mutton, duck & 0.1 ng DNA & Gel & {$[40]$} \\
\hline
\end{tabular}

${ }^{a}$ Species number; ${ }^{\text {b }}$ Chip, microchip electrophoresis; Gel, agarose gel electrophoresis.

Through the specificity test, we validated that the primers were highly specific to each of particular species and had no cross-reactivity, at least with the 15 animal species tested. The detection limit of this particular assay on reference meat samples was $0.01-0.05 \mathrm{ng}$, indicating that this method is highly sensitive and reliable. Using the DNA isolated from raw, boiled, autoclaved and microwave-cooked samples of seven meat species, simplex PCR assays generated all expected PCR products, suggesting that PCR assay with our primers had a high reproducibility in processed meat samples. Most importantly, multiplex PCR assay on commercially available processed meat products revealed that inexpensive chicken, duck and pork meats were adulterated products (Table 2 and Figure 4). Consistent with previous reports, inexpensive poultry meat readily evades visual detection and is frequently adulterated into other meat products, in particular, processed beef, mutton and pork [41-43]. Perhaps, economically driven thoughts of manufacturers or peddlers are a critical factor for the replacement of expensive, high-quality meat with inferior and low-cost ones. Collectively, the developed septuple PCR assay is not only reliable and efficient but is also a sensitive detection method for the identification of meat species in actual adulteration events. However, vegetable proteins such as soybean are found to a substitute ingredient for muscle proteins, due to their low cost of production $[8,38,44]$. In addition, some surveys demonstrate that inexpensive fish species are adulterated into meat products $[44,45]$. Therefore, we still cannot exclude the possibility that vegetable proteins and fish sources may be present in commercial meat products. Considering the 
fact that multiplex PCR with increased species-specific primers in one reaction may cause more opportunities of cross-reactivity with each other, or generated unexpected bands, a more efficient method for identification of meat adulteration should be developed in future study.

\section{Conclusions}

The aim of this study is to provide reliable adulteration detection, by means of septuple PCR, which can simultaneously authenticate seven animal species of turkey, goose, pig, sheep, beef, chicken and duck. The assay is also quite sensitive to enable detection of 0.01-0.05 ng DNA templates for each species per reaction, thus making it qualified for authenticating meat species in commercial, real-world foodstuffs. By simple agarose gel analysis, without expensive equipment or a high level of technical skill, this septuple PCR method could be more broadly used for detecting sources of meat species in foodstuffs in which adulteration is suspected.

Author Contributions: Z.C., Q.L. and D.P. contributed to the conceptualization, methodology, supervision, investigation and data curation; Z.C. and D.P. contributed to the funding acquisition; S.Z. and H.M. contributed to the software and data curation; X.Y., J.G. and J.C. contributed to the project administration and methodology; Z.C. and Q.L. contributed to the writing - original draft. All authors have read and agreed to the published version of the manuscript.

Funding: This work was financially supported by the National Natural Science Foundation of China (NSFC) (31901668 and 31972048), Scientific Research Fund of Zhejiang Provincial Education Department (Y201940932), the Natural Science Foundation of Ningbo (2019A610436), School Research Project in Ningbo University (XYL19011) and the Open Project Program of Beijing Key Laboratory of Flavor Chemistry, Beijing Technology and Business University (BTBU) (SPFW2020YB13).

Institutional Review Board Statement: Not applicable.

Informed Consent Statement: Not applicable.

Data Availability Statement: Not applicable.

Conflicts of Interest: The authors have declared no conflict of interest. This paper is our original unpublished work; it has not been published previously and is not under consideration for publication elsewhere, in whole or in part. All authors of this paper have read and approved the final, submitted version.

\section{References}

1. Li, Y.; Liu, S.; Meng, F.; Liu, D.; Zhang, Y.; Wang, W.; Zhang, J. Comparative review and the recent progress in detection technologies of meat product adulteration. Compr. Rev. Food Sci. Food Saf. 2020, 19, 2256-2296. [CrossRef] [PubMed]

2. Chung, S.M.; Hellberg, R.S. Effects of poor sanitation procedures on cross-contamination of animal species in ground meat products. Food Control. 2020, 109, 106927. [CrossRef]

3. Da Costa Filho, P.A.; Cobuccio, L.; Mainali, D.; Rault, M.; Cavin, C. Rapid analysis of food raw materials adulteration using laser direct infrared spectroscopy and imaging. Food Control. 2020, 113, 107114. [CrossRef]

4. Mansouri, M.; Khalilzadeh, B.; Barzegari, A.; Shoeibi, S.; Isildak, S.; Bargahi, N.; Omidi, Y.; Dastmalchi, S.; Rashidi, M.-R. Design a highly specific sequence for electrochemical evaluation of meat adulteration in cooked sausages. Biosens. Bioelectron. 2020, 150, 111916. [CrossRef] [PubMed]

5. Mokhtar, N.F.K.; El Sheikha, A.F.; Azmi, N.I.; Mustafa, S. Potential authentication of various meat-based products using simple and efficient DNA extraction method. J. Sci. Food Agric. 2019, 100, 1687-1693. [CrossRef] [PubMed]

6. Wang, W.; Wang, X.; Zhang, Q.; Liu, Z.; Zhou, X.; Liu, B. A multiplex PCR method for detection of five animal species in processed meat products using novel species-specific nuclear DNA sequences. Eur. Food Res. Technol. 2020, 246, 1351-1360. [CrossRef]

7. Barbin, D.F.; Badaró, A.T.; Honorato, D.C.; Ida, E.Y.; Shimokomaki, M. Identification of turkey meat and processed products using near infrared spectroscopy. Food Control. 2020, 107, 106816. [CrossRef]

8. Safdar, M.; Junejo, Y.; Arman, K.; Abasıyanık, M. A highly sensitive and specific tetraplex PCR assay for soybean, poultry, horse and pork species identification in sausages: Development and validation. Meat Sci. 2014, 98, 296-300. [CrossRef]

9. Tanabe, S.; Miyauchi, E.; Muneshige, A.; Mio, K.; Sato, C.; Sato, M. PCR method of detecting pork in foods for verifying allergen labeling and for identifying hidden pork ingredients in processed foods. Biosci. Biotechnol. Biochem. 2007, 71, 1663-1667. [CrossRef] 
10. Li, T.T.; Jalbani, Y.M.; Zhang, G.L.; Zhao, Z.Y.; Wang, Z.Y.; Zhao, X.Y.; Chen, A.L. Detection of goat meat adulteration by real-time PCR based on a reference primer. Food Chem. 2019, 277, 554-557. [CrossRef]

11. Li, J.; Li, J.; Xu, S.; Xiong, S.; Yang, J.; Chen, X.; Wang, S.; Qiao, X.; Zhou, T. A rapid and reliable multiplex PCR assay for simultaneous detection of fourteen animal species in two tubes. Food Chem. 2019, 295, 395-402. [CrossRef]

12. Leng, T.; Li, F.; Xiong, L.; Xiong, Q.; Zhu, M.; Chen, Y. Quantitative detection of binary and ternary adulteration of minced beef meat with pork and duck meat by NIR combined with chemometrics. Food Control. 2020, 113, 107203. [CrossRef]

13. Asensio, L.; González, I.; García, T.; Martín, R. Determination of food authenticity by enzyme-linked immunosorbent assay (ELISA). Food Control. 2008, 19, 1-8. [CrossRef]

14. Sentandreu, M.Á.; Sentandreu, E. Authenticity of meat products: Tools against fraud. Food Res. Int. 2014, 60, 19-29. [CrossRef]

15. Liu, G.; Luo, J.; Xu, W.; Li, C.; Guo, Y.; Guo, L. Improved triplex real-time PCR with endogenous control for synchronous identification of DNA from chicken, duck, and goose meat. Food Sci. Nutr. 2021. [CrossRef]

16. Li, J.; Li, J.; Liu, R.; Wei, Y.; Wang, S. Identification of eleven meat species in foodstuff by a hexaplex real-time PCR with melting curve analysis. Food Control. 2021, 121, 107599. [CrossRef]

17. Dolch, K.; Andrée, S.; Schwägele, F. Comparison of real-time PCR quantification methods in the identification of poultry species in meat products. Foods 2020, 9, 1049. [CrossRef] [PubMed]

18. Li, J.; Wei, Y.; Li, J.; Liu, R.; Xu, S.; Xiong, S.; Guo, Y.; Qiao, X.; Wang, S. A novel duplex SYBR green real-time PCR with melting curve analysis method for beef adulteration detection. Food Chem. 2021, 338, 127932. [CrossRef]

19. Zhu, T.; Zhou, X.; Zhang, W.; Wu, Y.; Yang, J.; Xu, L.; Chen, M.; Dong, W.; Xu, H. Multiplex and real-time PCR for qualitative and quantitative donkey meat adulteration. J. Food Meas. Charact. 2021, 15, 1161-1168. [CrossRef]

20. Li, T.; Wang, J.; Wang, Z.; Qiao, L.; Liu, R.; Li, S.; Chen, A. Quantitative determination of mutton adulteration with single-copy nuclear genes by real-time PCR. Food Chem. 2020, 344, 128622. [CrossRef]

21. Thanakiatkrai, P.; Dechnakarin, J.; Ngasaman, R.; Kitpipit, T. Direct pentaplex PCR assay: An adjunct panel for meat species identification in Asian food products. Food Chem. 2019, 271, 767-772. [CrossRef]

22. Fajardo, V.; González, I.; Rojas, M.; García, T.; Martín, R. A review of current PCR-based methodologies for the authentication of meats from game animal species. Trends Food Sci. Technol. 2010, 21, 408-421. [CrossRef]

23. Kumar, A.; Kumar, R.R.; Sharma, B.D.; Gokulakrishnan, P.; Mendiratta, S.K.; Sharma, D. Identification of species origin of meat and meat products on the dna basis: A review. Crit. Rev. Food Sci. Nutr. 2013, 55, 1340-1351. [CrossRef]

24. Ali, M.E.; Razzak, M.A.; Hamid, S.B.A.; Rahman, M.M.; Amin, M.A.; Rashid, N.R.A. Multiplex PCR assay for the detection of five meat species forbidden in Islamic foods. Food Chem. 2015, 177, 214-224. [CrossRef] [PubMed]

25. Galal-Khallaf, A. Multiplex PCR and 12S rRNA gene sequencing for detection of meat adulteration: A case study in the Egyptian markets. Gene 2021, 764, 145062. [CrossRef]

26. Vaithiyanathan, S.; Vishnuraj, M.R.; Reddy, G.N.; Kulkarni, V.V. Application of DNA technology to check misrepresentation of animal species in illegally sold meat. Biocatal. Agric. Biotechnol. 2018, 16, 564-568. [CrossRef]

27. Liu, W.; Tao, J.; Xue, M.; Ji, J.; Zhang, Y.; Zhang, L.; Sun, W. A multiplex PCR method mediated by universal primers for the identification of eight meat ingredients in food products. Eur. Food Res. Technol. 2019, 245, 2385-2392. [CrossRef]

28. Martín, I.; García, T.; Fajardo, V.; Rojas, M.; Pegels, N.; Hernández, P.E.; González, I.; Martín, R. SYBR-green real-time PCR approach for the detection and quantification of pig DNA in feedstuffs. Meat Sci. 2009, 82, 252-259. [CrossRef]

29. Pegels, N.; González, I.; Garcia, T.; Martín, R. Avian-specific real-time PCR assay for authenticity control in farm animal feeds and pet foods. Food Chem. 2014, 142, 39-47. [CrossRef]

30. Cheng, X.; He, W.; Huang, F.; Huang, M.; Zhou, G. Multiplex real-time PCR for the identification and quantification of DNA from duck, pig and chicken in Chinese blood curds. Food Res. Int. 2014, 60, 30-37. [CrossRef]

31. Iqbal, M.; Saleem, M.S.; Imran, M.; Khan, W.A.; Ashraf, K.; Zahoor, M.Y.; Rashid, I.; Rehman, H.-U.; Nadeem, A.; Ali, S.; et al. Single tube multiplex PCR assay for the identification of banned meat species. Food Addit. Contam. Part. B 2020, 13, $284-291$. [CrossRef]

32. Mafra, I.; Ferreira, I.M.P.L.V.O.; Oliveira, M.B.P.P. Food authentication by PCR-based methods. Eur. Food Res. Technol. 2008, 227, 649-665. [CrossRef]

33. Prusakova, O.V.; Glukhova, X.A.; Afanas'Eva, G.V.; Trizna, Y.A.; Nazarova, L.F.; Beletsky, I.P. A simple and sensitive two-tube multiplex PCR assay for simultaneous detection of ten meat species. Meat Sci. 2018, 137, 34-40. [CrossRef] [PubMed]

34. Dantas, V.V.; Cardoso, G.V.F.; Araújo, W.S.C.; De Oliveira, A.C.D.S.; Da Silva, A.S.; Da Silva, J.B.; Pedroso, S.C.D.S.; Roos, T.B.; De Moraes, C.M.; Lourenço, L.D.F.H. Application of a multiplex polymerase chain reaction (mPCR) assay to detect fraud by substitution of bovine meat cuts with water buffalo meat in Northern Brazil. CyTA J. Food 2019, 17, 790-795. [CrossRef]

35. Li, X.; Guan, Y. Specific identification of the adulterated components in beef or mutton meats using multiplex PCR. J. AOAC Int. 2019, 102, 1181-1185. [CrossRef]

36. Balakrishna, K.; Sreerohini, S.; Parida, M. Ready-to-use single tube quadruplex PCR for differential identification of mutton, chicken, pork and beef in processed meat samples. Food Addit. Contam. Part A 2019, 36, 1435-1444. [CrossRef] [PubMed]

37. Sultana, S.; Hossain, M.; Zaidul, I.; Ali, E. Multiplex PCR to discriminate bovine, porcine, and fish DNA in gelatin and confectionery products. LWT 2018, 92, 169-176. [CrossRef]

38. Safdar, M.; Junejo, Y. The development of a hexaplex-conventional PCR for identification of six animal and plant species in foodstuffs. Food Chem. 2016, 192, 745-749. [CrossRef] 
39. Qin, P.; Hong, Y.; Kim, H.-Y. Multiplex-PCR assay for simultaneous identification of lamb, beef and duck in raw and heat-treated meat mixtures. J. Food Saf. 2015, 36, 367-374. [CrossRef]

40. He, H.; Hong, X.; Feng, Y.; Wang, Y.; Ying, J.; Liu, Q.; Qian, Y.; Zhou, X.; Wang, D. Application of quadruple multiplex PCR detection for beef, duck, mutton and pork in mixed meat. J. Food Nutr. Res. 2015, 3, 392-398. [CrossRef]

41. Mane, B.; Mendiratta, S.; Tiwari, A. Polymerase chain reaction assay for identification of chicken in meat and meat products. Food Chem. 2009, 116, 806-810. [CrossRef]

42. Hou, B.; Meng, X.; Zhang, L.; Guo, J.; Li, S.; Jin, H. Development of a sensitive and specific multiplex PCR method for the simultaneous detection of chicken, duck and goose DNA in meat products. Meat Sci. 2015, 101, 90-94. [CrossRef] [PubMed]

43. Yacoub, H.A.; Sadek, M.A. Identification of fraud (with pig stuffs) in chicken-processed meat through information of mitochondrial cytochrome b. Mitochondrial DNA Part A 2016, 28, 855-859. [CrossRef] [PubMed]

44. Kim, M.-J.; Kim, H.-Y. Species identification of commercial jerky products in food and feed using direct pentaplex PCR assay. Food Control. 2017, 78, 1-6. [CrossRef]

45. Nejad, F.P.; Tafvizi, F.; Ebrahimi, M.T.; Hosseni, S.E. Optimization of multiplex PCR for the identification of animal species using mitochondrial genes in sausages. Eur. Food Res. Technol. 2014, 239, 533-541. [CrossRef] 